\title{
NEWS, VIEWS, AND COMMENTS
}

The Twin Children of Auschwitz-Birkenau:

Conference on Nazi Medicine/Research: Genes and DZ Twinning; IVF Versus Spontaneous Twinning; Gender Identity Disorder; Royal Protector: Danish and Australian Twin Registries/Human Interest: MZ Twin Co-Principals; Twin Loss at Sandy Hook; Twin Documentaries; New Twin and Twin-Like Reunions; Prominent Twins' Passing

\begin{abstract}
Nancy L. Segal
Department of Psychology, California State University, Fullerton, CA, USA

The twin children who survived the Holocaust and the horrific medical experiments conducted by Nazi doctors are sometimes overlooked in the relevant literature. This topic and more were discussed as part of an annual conference hosted by students from Yeshiva University's Medical Ethics Society in October 2012. A selective summary of this meeting is followed by summaries of recent twin studies concerning genetic influences on twinning, in vitro fertilization versus spontaneous twin pregnancies, gender identity disorder, and royal support for twin registries. Several human interest stories are also worth noting. They include identical twin school principals, twin loss at Sandy Hook Elementary School, timely twin documentaries, new twin and twin-like reunions, and the passing of two prominent twins.
\end{abstract}

\section{The Twin Children of Auschwitz-Birkenau: Conference on Nazi Medicine}

In January 1985 I attended the 40th anniversary reunion of the twin children who survived the Holocaust and the brutal experiments conducted on them by Dr Josef Mengele and other physicians (Segal, 1985, 1992, 2005). This reunion included a four-day gathering in Poland for memorials and other ceremonies at the Auschwitz-Birkenau concentration camp where the twins had been placed. This visit was followed by a three-day public hearing on Mengele's war crimes held at Yad VaShem ('Hand and Name', the World Center for Holocaust Research and Education) in Jerusalem. These events attracted worldwide attention and renewed determination to locate Dr Mengele and put him on trial. Six months later, Mengele's body was found in Embu, Brazil where he had been in hiding for many years. He had been the apparent victim of a drowning accident

ADDRESS FOR CORRESPONDENCE: Nancy L. Segal, Department of Psychology, California State University, Fullerton, CA 92834, USA. E-mail: nsegal@fullerton.edu 
in 1979, although some have questioned the truthfulness of this conclusion (Conroy, 1993).

It has been estimated that of the 1,500 twin pairs to pass through Auschwitz-Birkenau between spring 1943 and January 1945, only about 110 individual twins (in both intact and non-intact pairs) survived. The experience left deep emotional and physical scars on virtually all the twins.

The Holocaust literature tends to overlook the twins, perhaps because most of them were young children at the time. Their youth prevented many of them from understanding how and why their lives had been so cruelly uprooted. Following liberation, as they grew up, many kept their stories silent, although some did eventually speak out as adults. I would argue that this is precisely the reason why professional attention directed to this unique group of survivors was, and is, clearly warranted. In fact, over the years I often wondered why the testimony of the 30 mostly twin survivors recorded at the Jerusalem hearing had not been made public. I had heard the twins' stories over the course of the three-day event and was struck by the incredible breadth and detail of each twin's horrific and heartbreaking experience. I occasionally searched the Yad VaShem archives, believing that such material was important enough to warrant public dissemination. In 2012, with the assistance of an Israeli colleague, Ayana Kimron, I learned that the testimony had been translated and published, but only as recently as 2011 (Grodin et al., 2011). Unfortunately, the twins' testimonies appear in a highly specialized academic journal that few will see. I am hoping that the present article will make people aware of the availability of this material as well as the information presented at another more recent gathering.

On October 21, 2012, I attended a one-day conference in New York City, 'Out of the Ashes: Jewish Approaches to Medical Dilemmas Born Out Of the Holocaust', organized by student members of Yeshiva University's Medical Ethics Society. Highlights were a keynote address by Dr Michael Grodin of Boston University ('Medical Ethics in the Shadow of the Holocaust: The Nazi Doctors, Racial Hygiene, Murder, and Genocide'), and workshops by Dr Michael Berenbaum of the American Jewish University of Los Angeles ('Nazi Medicine: Its Role in the Gassing Process and the Ongoing Implications of Their Pseudo-Scientific Work') and Dr Dieter Kuntz of the United States Holocaust Memorial Museum in Washington, DC ('Nazi Physicians, Genetic Research, and the "Mission" of Racial Eugenics'). These scholars variously discussed the critical role of physicians in sustaining Germany's racial hygiene program, the nature of experimentation that involved both twins and non-twins in Auschwitz and other concentration camps, and the ethics surrounding the possible use of Nazi medical data today.

Scheduled among the academic talks was an exceptionally informative and moving presentation by twin survivor Irene Hizme. I had met Hizme and her twin brother Rene in 1984, just prior to leaving for my visit to AuschwitzBirkenau in 1985. Hizme has become a meaningful voice for all the twins through both lecture and film. She and her twin brother released a documentary film in 2005, Rene and I, which I viewed several years ago in southern California; a study guide is available and the link is provided at the end of the reference list. Hizme's calligraphy, which decorates many of the twins' plaques and programs, is stunning. I also spoke with her at length by telephone several weeks after the conference ended and consulted various online documentations of their lives; these links are also listed below. A picture of the twins when I first met them in New York City in 1984 is displayed in Figure 1.

Irene Hizme, nee Renate Guttmann, and her twin brother Rene were born in Teplice-Sanov, Czechoslovakia on December 21, 1937. Their parents were Herbert and Ita Guttmann. Just before their sixth birthday, the twins and their mother were transported to the Theresienstadt camp in Czechoslovakia, and then Auschwitz-Birkenau, in Poland. Their father had been arrested and killed at Auschwitz the year before. The twin children and their mother are shown in Figure 2.

Upon arrival in Auschwitz-Birkenau at the age of five, the twins were separated from their mother and from one another, having been assigned to sex-segregated barracks. They never saw their mother again. Like the other twins that were systematically identified at the Auschwitz-Birkenau railroad ramp and housed separately from the other prisoners, Rene and Irene were experimented upon. Rene was measured and had his blood analyzed continually. Irene received various painful treatments. The twins saw each other only once during their 13-month time in Auschwitz - a glimpse of one another over a barbed wire fence.

When the camps were liberated in January 1945, Rene was brought to Czechoslovakia by a physician, Dr Kalina, who treated him well. However, Kalina had to flee from the Communists and went to Israel, leaving Rene in the care of his sister. Meanwhile, Irene was cared for by a Polish woman who raised her as a Catholic, until she was located by a group searching for displaced Jewish children. Next, she stayed in a temporary home before entering an orphanage for Jewish children in Fublaine, France, about 125 miles south of Paris. The other children at the home had survived the war with the help of friends and relatives, whereas Irene was the only child who had been in a concentration camp. Then in 1947 when she was about nine years old, she and another boy, Charles Karo, were selected by Rescue Children to visit the United States (New York). Irene had, by now, adjusted to life in the orphanage and was promised that she would return after her New York visit. That never happened.

Irene's trip to New York was filled with various events, one of which was being filmed for the cover of Life magazine. There were also visits with prospective adoptive families, some of which did not go well. However, Irene was finally adopted by the Slotkin family of Long Island and they proved to be 'extraordinary - they did all they could do', Irene recalled. Most importantly, when her new family 


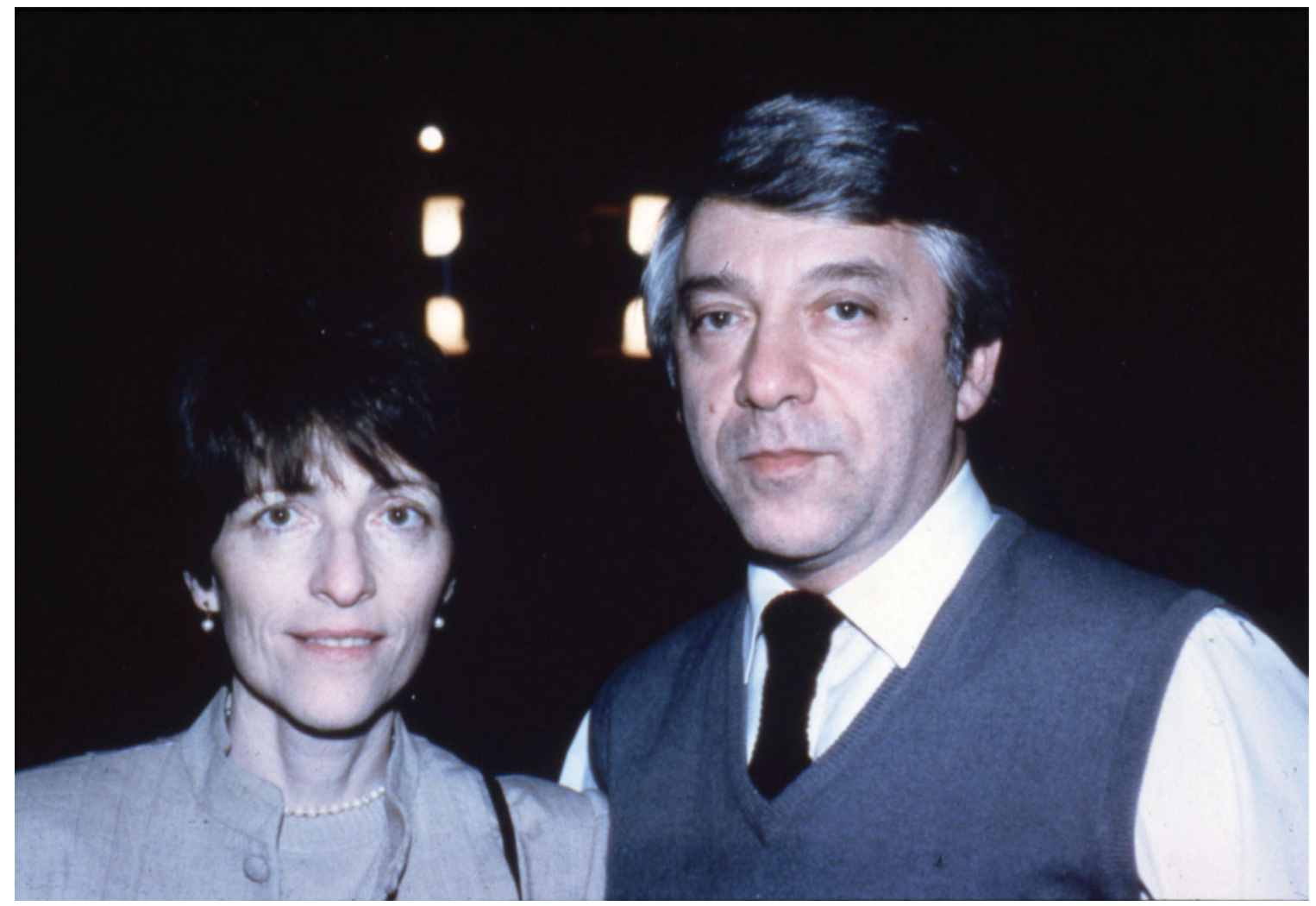

\section{FIGURE 1}

(Colour online) Irene and Rene Slotkin in New York City, 1984 (photo credit: Nancy L. Segal).

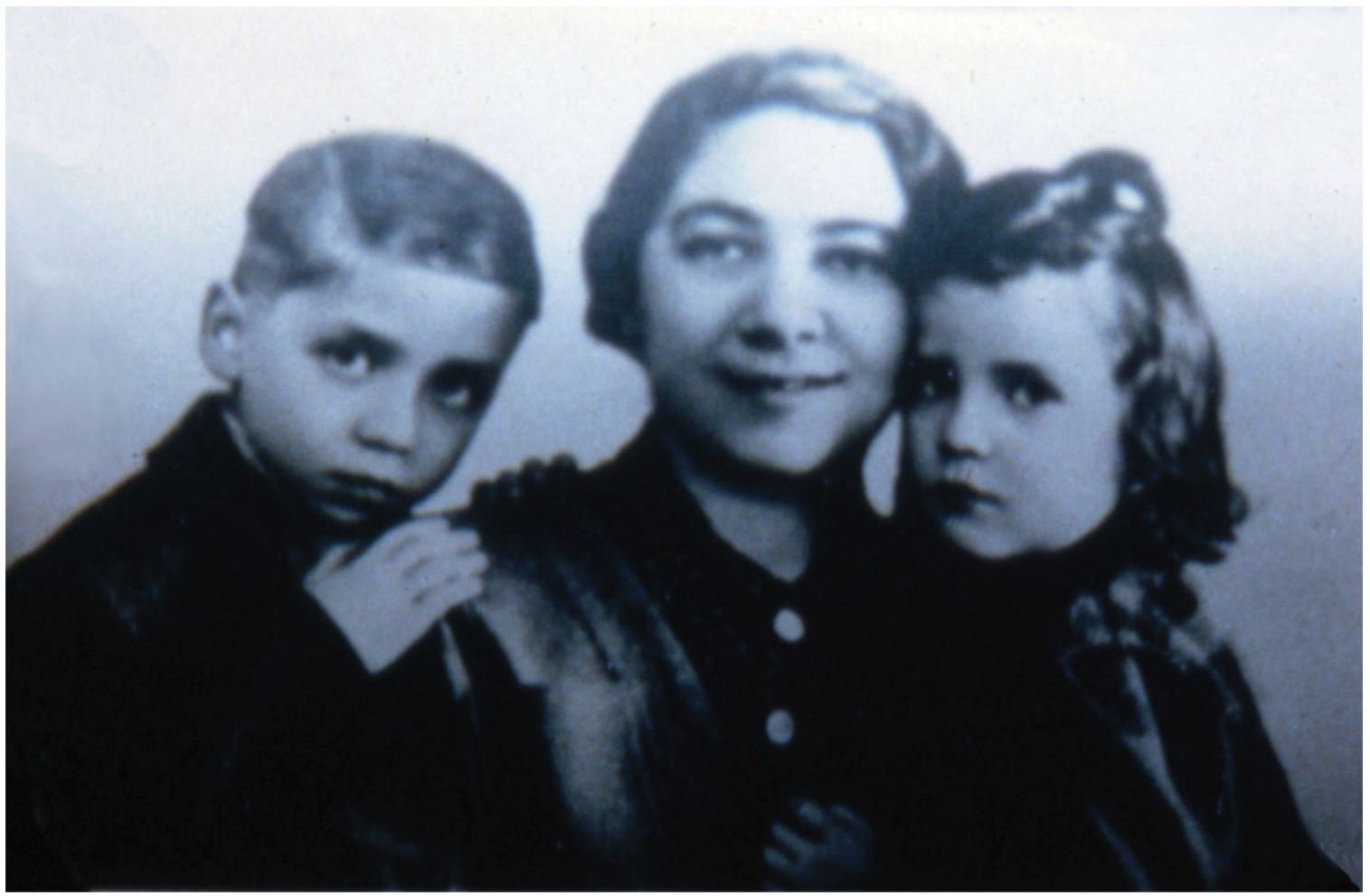

\section{FIGURE 2}

(Colour online) Rene, the twins' mother, and Irene (Renate). The twins were about five years old at this time (courtesy: the twins). 
learned that Irene had a twin brother, they began a serious search for him. Her adoptive father, who was in the furniture business, was well positioned and sought the assistance of then President Harry S. Truman. The family's search was assisted by a fortuitous event - Dr Kalina had seen the Life magazine's article with Irene's picture on the cover and was certain that she was his new son's twin sister. It is believed that he notified Rescue Children and the appropriate contacts were made.

The twins were reunited in the United States at the age of $12 \frac{1}{2}$ against all odds. Irene described their reunion at the airport: 'We were kind of at a loss for words - it was anticlimactic - there was no big kiss, but I knew it was my brother'. It had taken time for Rene to enter the United States due to the lengthy process of securing immigration papers and other documents that he eventually did with the assistance of a Slotkin family associate. During this time the twins exchanged letters, one of which included Irene's drawing of a pair of ice skates; she hoped to go skating with her brother once they met.

Reared-apart twins are the unique subset of twins whose life stories enchant, entertain, and inform. Every one reveals something new about human nature in general, and about twinship in particular. Irene and Rene were fortunate to be able to finally grow up together and to participate in each other's lives; in fact, both are married to twins and both have children and grandchildren. Unfortunately, not all the twin children were able to enjoy one another after Auschwitz some twins were separated and never reunited, and some twins lost their co-twins in the camp. One twin attended the Jerusalem hearing in the hope of locating his twin sister, but learned she had perished.

The Nazi science, with its aim of using twins to show the biological superiority of some people over others, set twin research back for a number of years. This was a serious misuse of twin methodology. In addition, there was a myriad of flaws in the experiments such as failure to distinguish between twin types and failure to always identify true twins (Segal, 1985). Above all, the twins were not consenting volunteers, but helpless children forced to participate in a horrific program of pseudo-scientific research activities. Their psychological and physical health hardly identified them as representative of the normal human condition. In striking contrast, current twin research purports to uncover the genetic and environmental bases of individual differences in behavioral, physical, and medical traits. The growing number of twin research projects, investigators, registries - and this journal — reflects its success. Above all, current researchers respect the health and well-being of their twin participants, and credit their generosity in publications.

Please read the moving story of another Auschwitz twin survivor's ongoing search for his twin brother (Strochlic, 2013).

\section{Research}

\section{Genes and Dizygotic (DZ) Twinning}

Dizygotic twinning is known to have a genetic component, although the molecular genetic bases of multiple ovulation and conception are less well understood. The twinning rate in Gambia, located in Western Africa, is 3\% of live births such that associations between genetic variants and DZ twinning are of interest in that nation. Sirugo and colleagues (2012), at the MRC Laboratories in Fajara, Gambia, assessed associations between genetic variation in the Pentraxin 3 (PTX3) gene and DZ twinning. PTX3 (which includes five single nucleotide polymorphisms or Single nucleotide polymorphisms [SNPS]) has been implicated in both female fertility and resistance to Mycobacterium tuberculosis pulmonary disease and Pseudomonas aeruinosa infection in cystic fibrosis patients. The study sample included 96 sisters and 34 half-sisters who had delivered DZ twins, and a control group of 95 women who had not delivered twins. No single SNP was associated with DZ twinning, but selected subsets and the entire group of five SNPs were associated among the related mothers of twins. This result confirms a previous finding from a study in Ghana.
Sirugo et al. (2012) noted in their introduction that the Yoruba of southwestern Nigeria in Western Africa have especially high twin $(45.1 / 1,000)$ and trizygotic triplet rates $(1.6 / 1,000)$. However, a recent report (also presented at the 2012 Twin Congress in Florence, Italy) identified Benin as having the highest twinning rate in that region, and probably in the world $(27.9 / 1,000)$ (Smits \& Monden, 2011).

\section{In Vitro Fertilization (IVF) Versus Spontaneous Twinning}

In vitro fertilization and other assisted reproductive technologies (ART) have dramatically increased the twinning rate in Western nations. The extent to which IVF twin pregnancies may pose greater risks to infants than to infants from naturally conceived twin pregnancies continues to be of importance. Polish investigators Szymusik et al. (2012) from the University of Warsaw examined pregnancy outcomes among women carrying twins. Forty-three women had conceived via IVF and 83 had conceived naturally. All pregnancies were dichorionic-diamniotic; monochorionic twin pregnancies were omitted because none were detected among mothers in the IVF group. Szymusik et al. 
concluded that the method of conception had no significant effect on the course of pregnancy, pre-term delivery, or obstetric outcome.

The authors noted that first trimester ART pregnancies are associated with increased bleeding and possible abortion among mothers carrying singletons, but not twins. They suggested that the general absence of monochorionicity (a known risk factor among monozygotic (MZ) twin pregnancies) among IVF twins might actually predict favorable outcomes for mothers and infants.

\section{Gender Identity Disorder}

There is a growing accumulation of case reports of $\mathrm{MZ}$ and DZ twins who are concordant or discordant for gender identity disorder. Researchers in Belgium and Canada have compiled and summarized the available case studies into a single literature review, enabling a fresh look at genetic and environmental factors underlying variation in this behavior. Heylens et al. (2012), from the Ghent University Hospital in Belgium, surveyed outcomes among 23 MZ male and female twin pairs, 21 DZ same-sex male and female twin pairs, and seven opposite-sex twin pairs. Consistent with genetic influence, nine (39.1\%) of the MZ twin pairs were concordant for gender identity disorder, in contrast with the DZ twin pairs, all of whom were discordant. Based on their results, the authors suggested cre- ating a registry of twin pairs, especially discordant pairs, to further explore sources of influence on gender identity disorder.

It is worth noting that one discordant $\mathrm{DZ}$ female twin pair was described as having 'many phenotypic characteristics in common' and being 'often mistaken as identical' (Heylens et al., 2012, p. 753). The method by which the zygosity of this pair was assessed could not be determined from the paper or the relevant citations. It remains possible that this pair was DZ; interestingly, the co-twin who identified as female was the only DZ co-twin in the series to indicate attraction to females.

\section{Royal Protector}

Danish and Australian Twin Registries: January 8, 2013 marked the second birthday of Danish Princess Josephine and her twin brother Prince Vincent. The twins were born to Crown Princess Mary and Crown Prince Frederik, who have two older children. At the birthday celebration it was announced that Crown Princess Mary would become an international patron of both the Danish and Australian Twin Registries. This news, marked by a special event held in Odense, Denmark on January 15, 2013, was attended by several hundred pairs of twins. I wish to thank Danish journalist and mother of twins Abelone Glahn (personal communication) for bringing this news to my attention.

\section{Human Interest}

\section{MZ Co-Twins and Co-Principals}

Ronald and Reginald Richardson are perhaps the only identical co-twins who are also co-principals at any elementary, middle, or high school (AP Press, 2012). Both twins graduated from San Francisco State University and obtained Master's degrees in education from the University of California, Berkeley. They then served as principals of neighboring elementary schools in Richmond, California before moving to their shared position in Oakland. They attribute their parallel careers to a common passion for teaching and leadership.

The Richardson twins remind me of another distinguished MZ twin pair, Drs Harold and Bernard Shapiro, who simultaneously held positions as president of Princeton University and McGill University, respectively (Segal, 2000). This pair, too, is illustrative of MZ twins' matched interests and talents, partly genetically based. However, while the Shapiro twins' responsibilities were similar, they were not shared - the Richardsons go a step further in combining commonality and cooperation.

\section{Twin Loss at Sandy Hook}

The tragic shooting at Sandy Hook Elementary School, in Newtown, Connecticut on December 14, 2012 killed 20 students and six adults (teachers and principal). Among the young students was six-year-old Noah Pozner (Huffington Post, 2013). His twin sister, Arielle, was in a different classroom, so survived. Twin loss poses unique circumstances for family members in that the surviving co-twin is a constant reminder of the twin who is no longer present. Birthdays may be particularly difficult days for all family members. My own research and legal consultation also shows that twin loss can be devastating for young survivors. Much more professional attention to twin loss during childhood is needed.

\section{Twin Documentaries}

1. A new documentary film, Hollywood to Bollywood, directed and edited by John Lavin, concerns 30-year-old identical twins, Garry and Larry Lane, who grew up gay in North 
Carolina (Holden, 2012). The twins moved to Los Angeles about one and a half years ago. The film records the twins' journey from California to the Dollywood theme park in Pigeon Forge, Tennessee, named after entertainer Dolly Parton. The twins wished to show Parton a film script they had been working on that included a role written expressly for her.

The twins revealed their sexual identity to one another when they were 16-year olds. In the film, they discuss their rejection by their mother when she learned this news at the time the twins turned 25 years. According to the review of the documentary, the twins' resiliency helped them through such difficult times.

2. The 1980 documentary film, Poto and Cabengo, tells the story of identical twins, Virginia and Grace Kennedy, whose private speech fascinated linguists and developmental psychologists. This film was released recently in the Criterion Collection's Eclipse series (Lim, 2012). These twins were studied extensively as six-year olds when their unusual speech, unintelligible to everyone but them, caused some language specialists to suspect that they were creating a new language. It turned out that they had incorporated aspects of their grandmother's German constructions and other speech elements into their speech. The twins grew up under somewhat isolated circumstances and spoke nearly exclusively to one another. I have seen neither of these two films, but believe they will interest readers of Twin Research and Human Genetics.

\section{New Twin and Twin-Like Reunions}

1. Mistaken identity was responsible for 18 (13.6\%) twin reunions among the 137 pairs (17 MZA and one DZA) participating in the Minnesota Study of Twins Reared Apart (Segal, 2012). Confusion based on physical resemblance also reunited Chinese MZ twins Bao Lulin and Yan Yanfei in December 2012 at the age of 24 (Medina, 2012). Bao Lulin had been mistaken repeatedly for her sister since June 2009 - at a restaurant, her workplace, and elsewhere and finally decided to find her. Lulin was unaware of being a twin, but was interested in finally finding her look-alike. Once she obtained Yanfei's address she visited her and it was clear that the two were identical twins. According to the news report, the two women were adopted separately as infants under their nations' One-Child Policy; however, further details of their separation were not provided. (The One-Child Policy limits urban families to one child and rural families to two.) The twins had many similarities, among them their year of marriage (2007), their husbands' name (Bin), and their sons' appearance ('almost identical' not surprising, since their sons are genetic 'half-siblings') as well as personality traits and food preferences.

My ongoing prospective study of young Chinese twins currently includes 12 reared apart pairs (seven MZA and five DZA) and 41 reared together pairs (37 MZT and four
DZT; Segal et al., 2011). Most reared together twins were found together, but information was unknown in some cases. Some reared apart twins were also found together, while some were found apart. Adoption officials told parents of these twins that China's practice is to keep abandoned twins together, but the parents indicated that it was difficult to know if such information was factual.

2. Physical resemblance recently reunited a pair of brothers born 13 months apart (Cernich, 2012). The boys, Dakotah Zimmerman and Isaac Nolting, were at a public swimming pool in Washington when they struck up a conversation. Dakotah, aware of the boys' physical similarities, mentioned that he had a brother adopted away 10 years earlier. Dakotah mentioned that the woman who had adopted his brother was named Dawn — Dawn was Isaac's mother's name. However, Isaac did not know he had been adopted. The boys had been born to a teenage mother who could not manage to raise two near-in-age infants. Both biological parents are now deceased and Dakotah has a legal guardian. The two families celebrated Dakotah's birthday together for the first time, a happy occasion for everyone.

This situation highlights the physical variation that can be expected among full siblings and fraternal twins. Most DZ twins in the Minnesota Study of Twins Reared Apart were reunited after an extensive search; however, DZ twins in one pair did meet due to their striking physical resemblance. A photo of these twins appears in my recent book about the study (Segal, 2012, p. 40).

\section{Prominent Twins' Passing}

The fields of neurology and adoption research lost two prominent contributors in December 2012. Rita LeviMontalcini of Italy, passed away at the age of 103 in Rome (Notable Names Database [NNDB], 2013). In May 2008, Levi-Montalcini, a DZ twin, became the longest-living Nobel Prize winner, surpassing Tadeus Reichstein (famous for work on hormones of the adrenal cortex that culminated in the isolation of cortisone and its use in treating rheumatoid arthritis) who died at the age of 99 (Nobelprize.org, 2013). Her joint discovery of nerve growth factor (NGF) and epidermal growth factor (EGF) with Stanley Cohen earned them a joint Nobel Prize for Medicine in 1986.

Rita Levi-Montalcini began her career as a neurologist, but when the academic careers of Jewish people were restricted in the 1930s she secretly conducted research on chickens in her home. After the war she accepted a one-year research position at Washington University in St. Louis, and remained there for 30 years. Levi-Montalcini's twin sister, Paola, was an artist who passed away in 2000 at age 91 years. I was honored to have met Rita Levi-Montalcini at the VI International Congress of Twin Studies in 1989 in Rome, Italy.

The world of adoption lost another twin, social worker Reuben Pannor. Panor and his twin brother Harry were 
born on July 4, 1922 in a small Lithuanian village. Antisemitism brought the family to the United States before the twins turned seven. Both twins became social workers.

Reuben Pannor is famous for his research and advocacy of open adoption - the idea that birth parents can maintain contact with the children they relinquished for adoption. This concept was controversial in the 1950s, 1960s, and 1970s because many feared that bringing birth parents into an adoption situation would interfere with the bond between the adoptive parents and child. However, Pannor believed that everyone has a right to know their family's history and genealogy. This view may explain why he also became a spokesperson for unwed fathers.

Pannor is probably best remembered for his book The Adoption Triangle, published in 1976 with a recent edition in 2008. Pannor is this book's third author; his two coauthors were Arthur D. Sorosky and Annette Baron. The book, which makes the case for open adoption, is considered a classic in the field.

\section{References}

AP Press. (2012). Twins paired up as co-principals of California school. Accessed on March 12, 2013. Retrieved from http://m.apnews.com/ap/db_268743/contentdetail? contentguid $=$ Emar8ZWp

Cernich, K. (2012, August 29). An unexpected family reunion. Emissourian. Accessed on March 12, 2013. Retrieved from http://www.emissourian.com/features_people/feature stories/article_5ea60d44-f15c-11e1-82a2-

0019bb2963f4.html

Conroy, J. (1993, November 23). On the trail of Josef Mengele. Chicago Reader. Accessed on March 12, 2013. Retrieved from http://www.chicagoreader.com/chicago/onthe-trail-of-josef-mengele/Content? oid $=883306$

Grodin, M. A., Kor, E. M., \& Benedict, S. (2011). The trial that never happened: Josef Mengele and the twins of Auschwitz. War Crimes, Genocide and Crimes Against Humanity, 5, 389.

Heylens, G., De Cuypere, G., Zucker, K. J., Schelfaut, C., Elaut, E., Vanden Bossche, H., ... T'Sjoen, G. (2012). Gender identity disorder in twins: A review of the case report literature. Journal of Sexual Medicine, 9, 751-757.

Holden, S. (2012, August 30). Wishing on, and seeking out a star. New York Times. Accessed on March 12, 2013. Retrieved from http://movies.nytimes.com/2012/08/31/ movies/hollywood-to-dollywood-a-documentary.html

Huffington Post. (2013, 10 January). Family of Noah Pozner, Newtown shooting victim, contacted by white house about gun control. Accessed on March 12, 2013. Retrieved from http://www.huffingtonpost.com/2013/01/10/ noah-pozner-family-gun-control-n_2452664.html

Lim, D. (2012, February 5). Gorin's stranger in a strange land. Los Angeles Times, p. D8.

Medina, S. (2012, December 5). Bao Lulin and Yang Yafei, identical twins separated at birth, find each other 24 years later. Huffington Post. Accessed on March 12, 2013. Retrieved from http://www.huffingtonpost.com/2012/12/05/ bao-lulin-and-yang-yanfei_n_2245622.html

Nobelprize.org. (2013, January 12). Tadeus Reichstein Biography. Accessed on March 12, 2013. Retrieved from http://www.nobelprize.org/nobel_prizes/medicine/ laureates/1950/reichstein-bio.html

Notable Names Database (NNDB). (2013, January 12). Rita Levi-Montalcini. Accessed on March 12, 2013. Retrieved from http://www.nndb.com/people/062/000132663/

Segal, N. L. (1985). Holocaust twins: Their special bond. Psychology Today, 19, 52-58.

Segal, N. L. (1992). Twin research at Auschwitz-Birkenau: Implications for the use of Nazi data today. In A. Caplan (Ed.), When medicine went mad: Bioethics and the holocaust (pp. 281-299). Totowa, NJ: Humana Press.

Segal, N. L. (2000). Entwined lives: Twins and what they tell us about human behavior. New York: Plume.

Segal, N. L. (2005). Indivisible by two: Lives of extraordinary twins (chapter 7). Cambridge, MA: Harvard University Press.

Segal, N. L. (2012). Born together-reared apart: The landmark Minnesota twin study. Cambridge, MA: Harvard University Press.

Segal, N. L., Stohs, J. H., \& Evans, K. (2011). Chinese twin children reared apart and reunited: First prospective study of co-twin reunions. Adoption Quarterly, 14, 61-78.

Sirugo, G., Edwards, D. R. V., Ryckman, K. K., Bisseye, C., White, M. J., Kebbeh, B., ... Williams, S. M. (2012). PTX3 genetic variation and dizygotic twinning in the Gambia: Could peliotropy with innate immunity explain common dizygotic twinning Africa? Annals of Human Genetics, 76, 454-463.

Smits, J., \& Monden, M. (2011). Twinning across the developing world. PLoS ONE, 6, e25239.

Sorosky, A., Baran, A., \& Pannor, R. (2008). The Adoption Triangle. Las Vegas, NV: Sacred Healing.

Strochlic, N. (2013). An Auschwitz survivor searches for his twin on Facebook. The Daily Beast. Accessed on March 12, 2013. Retrieved from http://www.thedailybeast.com/ articles/2013/03/10/an-auschwitz-survivor-searches-forhis-twin-on-facebook.html

Szymusik, I., Kosinska-Kaczynska, K., Bomba-Opon, D., \& Wielgos, M. (2012). IVF versus spontaneous twin pregnancies - which are at higher risk of complications? Journal of Maternal-Fetal and Neonatal Medicine, 25, 2725-2728.

\section{Rene and Irene: Links}

Rene and I (study guide)

http://holocausteducation.org/pdf/Rene_\&_I_study_guideweb_format.pdf

http://digitalassets.ushmm.org/photoarchives/detail.aspx?id= 1151062 \&search $=$ TWINS\&index $=14$

http://www.namesnotnumbers.org/student_research_Rene _Slotkin.html 